\title{
Religious Sentiment in the Muslim Malaysia: Rationality and the Religious Belief
}

\author{
Mohd Arip Kasmo ${ }^{1}$, Abur Hamdi Usman ${ }^{2}$, Wan Zulkifli Wan Hassan ${ }^{1}$, Zulkifli Muhamad ${ }^{1}$, Nasruddin Yunos ${ }^{1}$, \\ Azwira Abdul Aziz ${ }^{1} \&$ Abdul Salam Yusuf ${ }^{1}$ \\ ${ }^{1}$ Centre for General Studies, The National University of Malaysia, Malaysia \\ ${ }^{2}$ Institute of Islam Hadhari, The National University of Malaysia, Malaysia \\ Correspondence: Abur Hamdi Usman. Institute of Islam Hadhari, The National University of Malaysia, Selangor, \\ 43600, Malaysia. Tel: 60-166-905-082. E-mail: aburhamdiusman@yahoo.com
}

Received: November 14, 2014 Accepted: January 8, 2015 Online Published: February 25, 2015

doi:10.5539/res.v7n3p171

URL: http://dx.doi.org/10.5539/res.v7n3p171

\begin{abstract}
This paper reports a study on the reaction of the Muslim in Malaysia toward provocative action on Prophet Muhammad. 700 respondent males and females, who were obtained randomly throughout Malaysia participated in the study which aimed at identifying the Muslim reactions toward provocative actions against Prophet Muhammad. The provocative actions include defaming, vilifying and insulting the Prophet. The respondents were given booklets of questionnaire containing statements which were provided with the Likert type scales, ranging from 1. Strongly agree, 2. Agree, 3. Not sure, 4. Disagree, and 5. Strongly disagree. The respondents were asked to response to the questionnaire and after 30 minutes, the booklet was collected. The data which was obtained was analysed using the SPSS to find the percentage, the means and the correlation. The findings show that very high percentage of the respondents were offended and prepared to fight if the Prophet is vilified and insulted. The finding also shows that the Muslim seems to be more easily agitated when Prophet is vilified compared to practicing the teaching of Prophet. The finding shows that $95.3 \%$ of the respondents were angry when Prophet is insulted while the respondents who practiced the teaching of the Prophet Muhammad was $85.7 \%$.
\end{abstract}

Keywords: religious, sentiment, defamation, rationality, Malaysia

\section{Introduction}

The world has seen the Muslims' reactions toward provocative insults and vilification hurled toward Prophet Muhammad. Defamation of the Prophetic not a new phenomenon, and has been going on since the Prophet time itself when he started to preach Islam (Armstrong, 2004). In the past, defamation against the prophet went unnoticed by the majority of the Muslims masses, but by the advent of the internet and other form of information and communication technology, the news on the defamation against the prophet spread like fire and drew anger of the Muslims throughout the world.

The short film Innocence Muslim has caused the Muslim anger throughout the world. Prophet Muhammad is very dear to the Muslim because he is the embodiment of the Islamic teaching, and vilifying Prophet is considered vilifying Islam and the Muslim themselves. Although many Muslim are angry when the Prophet is vilified and insulted, question remains to be asked whether the Muslim really love the prophet by practicing the teachings of the Prophet. Therefore, the study intends to see if there is correlation between the emotion of the Muslim toward the Prophet and what they practice.

\section{Literature Review}

Vilification and insult against the Prophet Muhammad had actually started at the time of the Prophet himself in the $6^{\text {th }}$ century Mecca. One example of the vilification was what Abu Jahl, the leader of the people in Mecca at that time did to the prophet when the later was praying in the Kabah (Andrea, 2013). Abu Jahl asked his friend to bring dirty foetus of a she-camel and placed it on the back of the prophet while other people laughed at the prophet. The story of the vilification and insult of the prophet did not end there, but it continued until the present days.

There are however many people among the non-Muslims who commended Prophet Muhammad in their writings, 
among them are Hart (1992) where he ranked the Prophet as the most influential man in human history. A French writer, Lamartine (1854) had the same idea as Hart by saying that if greatness of purpose, smallness of means, and astounding results are the three criteria of human genius, who could dare to compare any great man in modern history with Muhammad. Gibbon (1870) wrote favourably about the Prophet by saying it is not the propagation but the permanency of his religion that deserves our wonder, the same pure and perfect impression which he engraved in Mecca and Medina is preserved the revolutions of twelve centuries by the Indian, the African and the Turkish proselytes of the Qur'an. Tritton (2003) rejected the allegation that Prophet Muhammad mission was spread by sword. In his book he said "The picture of Muslim soldier advancing with a sword in one hand and the Qur'an in the other is quite false". Goethe the German poet discussed Prophet Muhammad in a positive way where he praised Prophet Muhammad and said Muhammad as the best mankind (Mommsen, 2014). Carlyle et al. (1993), dubbed the prophet Muhammad as a great hero and said that none of the allegations against the prophet were true.

The contemporary writers on prophet Muhammad for example Armstrong (1993) wrote favourably about the prophet by saying that the prophet preached loyalty to god rather than tribe, reconciliation rather that retaliation, care for the orphan and the poor and empowerment to women. Armstrong (1993) further noted that the prophet was a tireless campaigner against greed, injustice and arrogance.

Although many writers wrote favourably about the Prophet Muhammad, some writers still follow the footsteps of some of the earlier writers who insinuated the Prophet Muhammad among them were Muir (1861), the British Orientalist who denigrated the Prophet Muhammad and said that the prophet was epileptic and other wild allegations against the prophet. Rushdie (1988), an Indian novelist whose novel The Satanic Verse triggered the anger of the Muslim throughout the world because of his vilification of the prophet in his novel. Rushdie's novel was based on certain historical account of the prophet and her wife Aisha (Erikson, 1998). The book was written in a vilifying way, to purposely offend the believers.

Recent events have shown that the vilification of the prophet seem to be getting the sanction of the western governments under the pretext of free speech. Notably among them the Danish Daily Newspaper, Jyllands-Posten which published cartoons depicting the Prophet Muhammad and the French Satirical weekly Charlie Hebdo. The magazine has published lewd caricatures of the Prophet Muhammad. A short film which was uploaded into the YouTube Innocence Muslim purposely made to offend the Muslim, drawing protest all over the Muslim countries (Lane et al., 2012).

The long list of the people who has vilified the Prophet Muhammad continued with Ali (2008), who wrote the book Infidel with the forwarding statement by Hitchens, the author of the book God Is Not Great. The content of the book which insulted the Prophet infuriated the Muslim all over the world. Wilders, the head of the Dutch right wing party created uproar among the Muslim when he published the film Fitna which vilified Islam and the Prophet (Deresky et al., 2011). Surprisingly the man behind the scene who created the film, Arnold Van Doon himself embraced Islam, after reading the Qur'an in his effort to understand the reason why Muslim was angered by the film (Winston, 2014).

Since Islam is universal in nature, anything which touches the sensitivity of the Muslims will immediately be felt by the Muslim in Malaysia. For example, the Muslim Non-Governmental Organisations in Malaysia closed their ranks in condemning Salman Rushdie for writing the novel the Satanic Verse in which he insulted Prophet Muhammad and his wife Aisha. When he was knighted by Queen Elizabeth II on June 16, 2006, there was a mass demonstration in Malaysia condemning the award (Patterson, 2014). The Association of Malaysia Muslim Scholars (PUM) was one of forefront on attacks on several Malaysia writers and public intellectuals who were accused of Insulting Islam and Prophet Muhammad (Liow, 2009).

\section{Methodology and Analysis}

The research was conducted among 700 respondents male and female from the age of 15 to 60 years old from all over the country. They were obtained randomly and each respondent was given a booklet of questionnaire containing statements which have to be responded by the respondents. Each statement was provided with five choices of responses ranging from 1. Strongly agree, 2. Agree, 3. Not sure, 4. Disagree, and 5. Strongly disagree.

The statements which were asked to the respondents were: 1). I always praise to the prophet Muhammad, 2). I try to practice the teaching of the prophet Muhammad, 3). I am angry when someone vilifies Prophet Muhammad, and 4). I am prepared to fight if somebody vilifies Prophet Muhammad.

The Likert style scale was used in this study because it measures attitude of the respondents. Kothari (2011) listed five reasons why Likert scale is good instrument of test. The five reasons are: First, it is relatively easy to 
construct. Second, it is more reliable instrument because under it, respondents answer each statement included in the instrument. Third, each statement included in the Likert scale is given an empirical test for discriminating ability. Fourth, Likert scale can easily be used. Fifth, it is take less time to construct. The responses were analysed using the SPSS, to find the percentages, the means, correlation and difference of means.

The first statement which analysed was "I always praise the prophet Muhammad". The result of the analysis is shown in the following Table 1.

Table 1. Percentage of the response for the statement 1

\begin{tabular}{ccccc}
\hline & Frequency & Percent & Valid Percent & Cumulative Percent \\
\hline Strongly agree & 306 & 43.3 & 46.5 & 46.5 \\
Agree & 303 & 42.9 & 46.0 & 92.6 \\
Not sure & 42 & 5.9 & 6.4 & 98.9 \\
Disagree & 3 & .4 & .5 & 99.4 \\
Strongly disagree & 4 & .6 & .6 & 100.0 \\
\hline
\end{tabular}

Table 1 shows that the percentage of the respondents who strongly agree with the statement 1. "I always praise the Prophet Muhammad" is $43.3 \%$, those who agree is $42.9 \%$, those who is not sure is $5.9 \%$, those who disagree was $0.4 \%$ and those who strongly disagree is $0.6 \%$. The total percentage of the respondents who accept the statement is therefore $86.2 \%$ which is a big percentage. Those who did not accept the statement is $1.0 \%$. Hence, the percentages of the responses are converted into bar chart as shown in Figure 1.

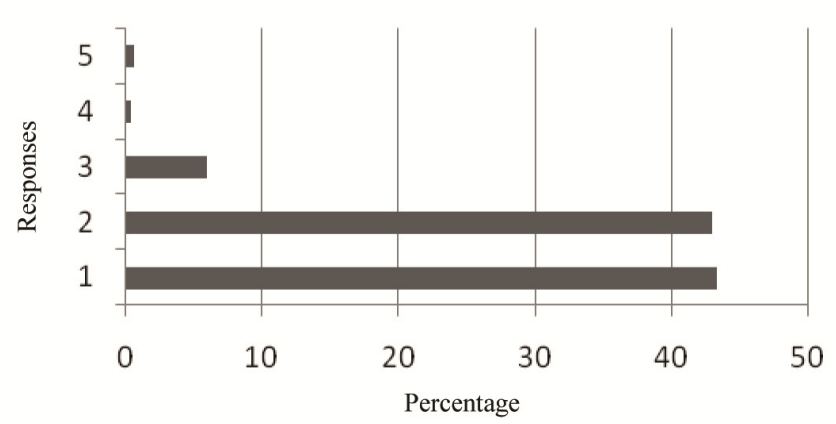

Figure 1. Bar chart for the responses "I always praise to the Prophet"

Figure 1 shows the responses can be clearly seen response 1 ( strongly agree) and response 2 (agree) show that the respondents do love Prophet Muhammad, because praising the Prophet by saying "Peace be upon him" his name is mentioned show that someone regard that the Prophet is very dear to him or her.

Moreover, the next statement which was analysed was "I practice the teaching of the prophet Muhammad". The result of the analysis is shown in the following Table 2.

Table 2. The percentages of the response for the statement 2

\begin{tabular}{ccccc}
\hline & Frequency & Percent & Valid Percent & Cumulative Percent \\
\hline Strongly agree & 279 & 39.5 & 42.4 & 42.4 \\
Agree & 285 & 40.4 & 43.3 & 85.7 \\
Not sure & 86 & 12.2 & 13.1 & 98.8 \\
Disagree & 5 & .7 & .8 & 99.5 \\
Strongly disagree & 3 & .4 & .5 & 100.0 \\
\hline
\end{tabular}


Table 2 shows the percentage of the response for the statement 2. "I practice the teaching of the Prophet" is $42.4 \%$ of the respondents strongly agree with the statement, $43.3 \%$ agree. The respondents who disagree with the statement was $0.8 \%$ and strongly disagree was $0.5 \%$. This means that $85.7 \%$ of the respondent accepted the statement (combination of response 1 and 2), 13.1\% was not sure and 1.3\% rejected the statement (combination of response 4 and 5). This means that $1.3 \%$ of the respondent rejected the statement. Hence, the percentages of the responses are plotted into a bar chart to be easily seen as shown in Figure 2.

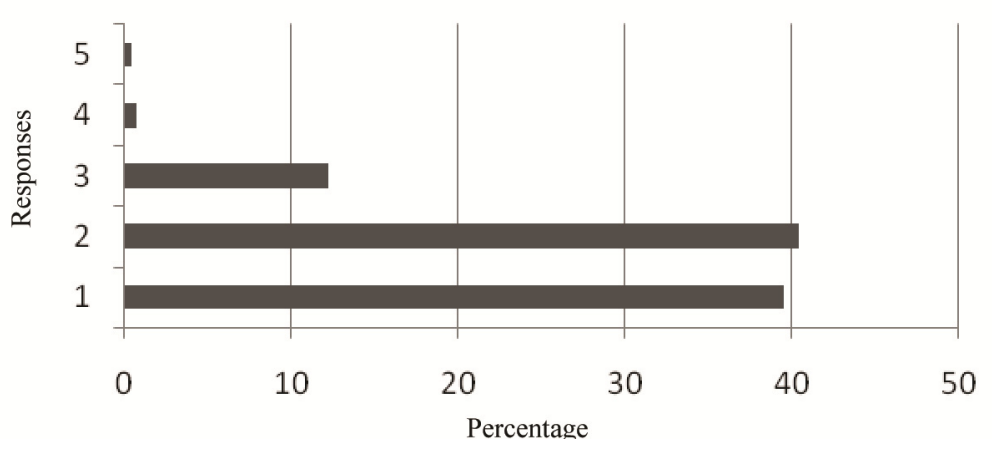

Figure 2. The bar chart of the percentages of the responses for the statement 2

Figure 2 shows the percentages of the responses. Majority of the respondents accepted the statement "I practice the teaching of the Prophet Muhammad". Furthermore, the next statement which was analysed was "I am angry when Prophet Muhammad is insulted". The result of the analysis is shown in the Table 3.

Table 3. The percentage of the response for the statement 3

\begin{tabular}{ccccc}
\hline & Frequency & Percent & Valid Percent & $\begin{array}{c}\text { Cumulative } \\
\text { Percent }\end{array}$ \\
\hline Strongly agree & 467 & 66.1 & 70.9 & 70.9 \\
Agree & 161 & 22.8 & 24.4 & 95.3 \\
Not sure & 27 & 3.8 & 4.1 & 99.4 \\
disagree & 2 & .3 & .3 & 99.7 \\
Strongly disagree & 1 & .1 & .2 & 99.8 \\
\hline
\end{tabular}

Table 3 shows that the percentage of the respondents who strongly agree with the statement 3. "I am angry when Prophet Muhammad is insulted" is $70.9 \%$, those who agree is $24.4 \%$, not sure $4.1 \%$. While disagree $0.3 \%$ and strongly disagree is $0.2 \%$. Hence, the percentages of the respondent who accept the statement 3 is $95.3 \%$, (combination of response 1 and 2), those who were not sure was $4.1 \%$, and those who rejected the statement was $0.5 \%$ (combination of response 4 and 5 ) and converted into a bar chart as sown in Figure 3.

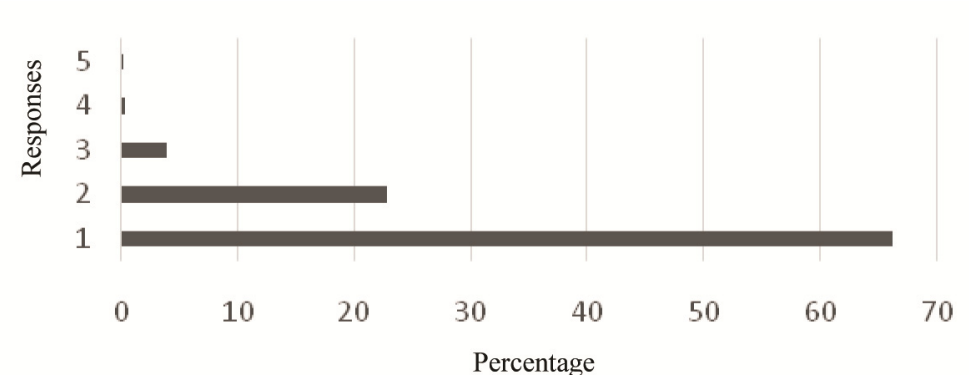

Figure 3. The bar chart of the percentages of the responses for the statement 3 
Figure 3 shows that the majority of the respondents accepted the statement 3 "I am angry when the Prophet Muhammad is insulted". In addition, the next analysis is on the response of the statement "I am prepared to fight if Prophet Muhammad is insulted". The percentages of the responses are shown in Table 4.

Table 4 . The percentage of the response for the statement 4

\begin{tabular}{ccccc}
\hline & Frequency & Percent & Valid Percent & Cumulative Percent \\
\hline Strongly agree & 379 & 53.7 & 57.8 & 57.8 \\
Agree & 205 & 29.0 & 31.3 & 89.0 \\
Not sure & 67 & 9.5 & 10.2 & 99.2 \\
Disagree & 3 & .4 & .5 & 99.7 \\
Strongly disagree & 2 & .3 & .3 & 100.0 \\
\hline
\end{tabular}

Table 4 shows that the percentage of the respondents who strongly agree with the statement 4 . "I am prepared to fight if Prophet Muhammad is insulted" is $57.8 \%$ those who agree is $31.3 \%$. These mean that the percentage of the respondents who accepted the statement is $89.1 \%$ (combination of response 1 and 2). The percentage of the respondents who were not sure was $10.2 \%$ and those who disagree were $0.5 \%$ and those who strongly disagree was $0.3 \%$. The percentages of the responses are converted into bar chart as shown in Figure 4.

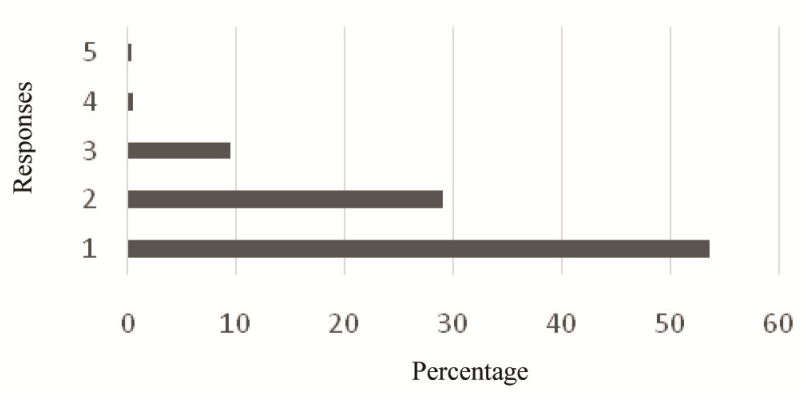

Figure 4. The percentages of the response for the statement 4

Figure 4 shows that the majority of the respondents $89.1 \%$ of the respondents accept the statement 4 . In other word, all the percentages of the responses for all of the statements are plotted to form line graph as shown in Figure 5.

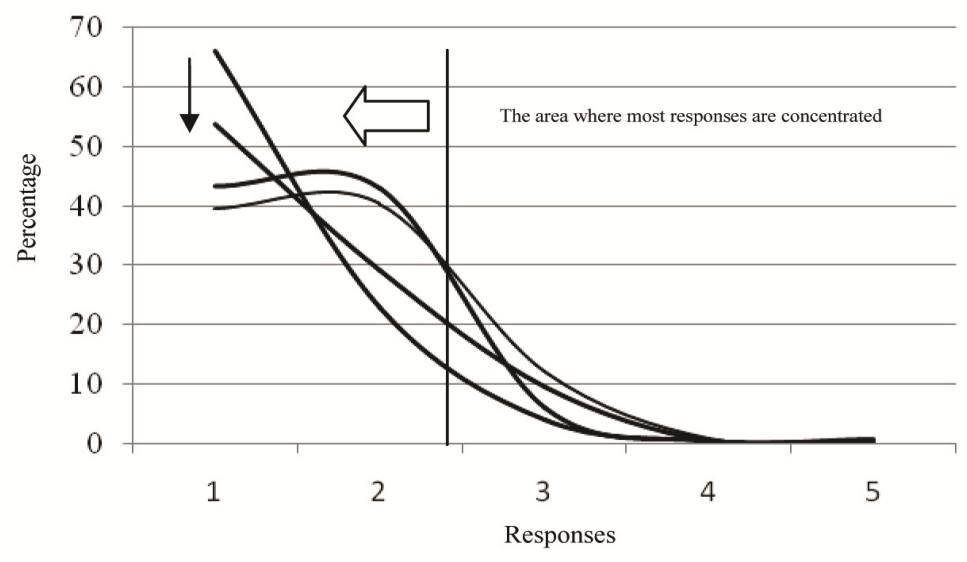

Figure 5. Percentage curve graph of the response 
Figure 5 shows that the percentages of the responses differ from one statement to the other. However the strongest reaction of the respondents is the feeling of anger when the prophet Muhammad is insulted the anger i.e., almost $90 \%$ of the respondent were angry when Prophet Muhammad is insulted.

\subsection{The Mean Analysis}

Moreover, the mean response for the responses of all the statements is analysed. The results of the analysis is shown in the following Table 5.

Table 5. Mean responses for the statements

\begin{tabular}{lc}
\hline & Mean \\
\hline I praised the Prophet ( i.e. saying peace be upon him) & 1.6261 \\
I practice the teaching of the Prophet Muhammad is insulted & 1.7356 \\
I am prepare to fight if Prophet Muhammad is insulted & 1.5427 \\
I am angry if Prophet Muhammad is insulted & 1.3414 \\
\hline
\end{tabular}

Table 5 shows that the mean is smallest for the statement "I am angry when the prophet Muhammad is insulted". The mean response is 1.314 , which is very close to 1 , i.e., strongly agree. The next smallest is for the mean response for the statement "I am prepare to fight when the prophet Muhammad is Insulted". The mean response for the statement is 1.5427 . The mean response for the statement "I always praise the prophet Muhammad" is 1.6262 and the mean response for the statement "I practice the teaching of the prophet Muhammad" is 1.7356 . Thus, the mean responses are plotted into a graph to see the pattern of the response. The following Figure shows the line curves graph for all the mean responses according to different statements.

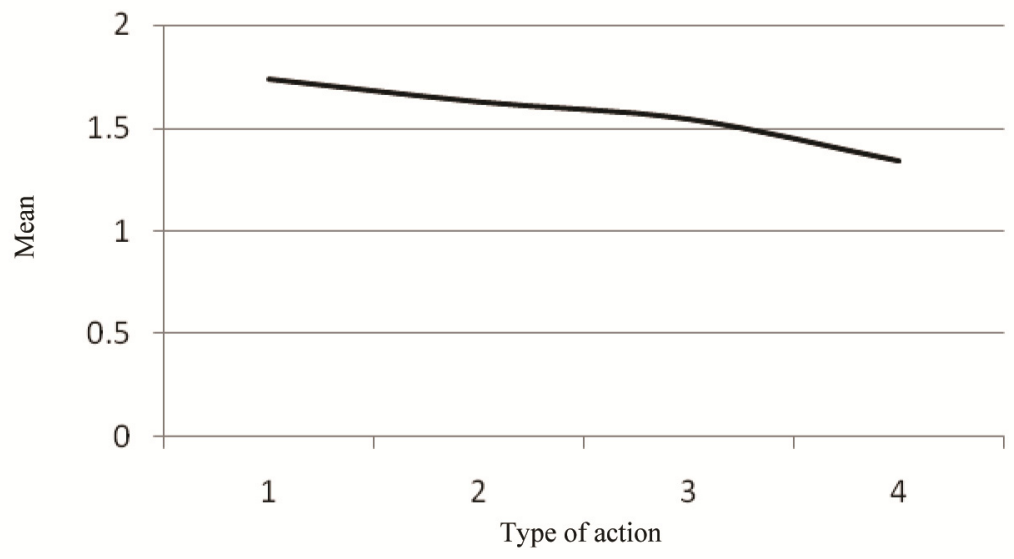

Figure 6. The line graph for the mean responses

Figure 6 shows that the mean responses gradually decreases from practising the teaching of the Prophet to praising the Prophet (i.e., by saying peace be upon him), to prepare to fight and the last is to get angry.

\section{The Findings and Discussion}

The findings of the study indicate that the Muslim in Malaysia is sensitive to act of defaming, insulting and vilifying the Prophet Muhammad. The data analysis shows that $95.3 \%$ of the respondents were angry when the prophet is insulted (See Table 3). The percentage of the respondents who always praised the Prophet Muhammad was $92.5 \%$. The percentage of the respondents who were prepared to fight when the prophet Muhammad is insulted was $89.1 \%$ and the percentage of the respondents who practiced the teaching of the prophet Muhammad was $85.7 \%$, which was less than those who were angry when the prophet Muhammad was insulted. These percentages indicate that Muslims were easily swayed by emotion when Prophet Muhammad is defamed. The Muslims in Malaysia just like the rest of the Muslim throughout the world are sensitive to the act of the defamation of Prophet Muhammad. Their reaction is similar to the reaction of the Muslim in Egypt, Sudan and 
Indonesia and the other Muslim countries (Gorder, 2014).

The feeling of anger of the Muslim when Prophet Muhammad is defamed could be understood because the proclamation that "There is no deity worthy of worship except Allah and that Muhammad is the messenger of Allah" is the first article of faith. Practicing Muslim would proclaim the first article of faith 17 times daily during their prayers (Dowling \& Scarlett, 2005). Therefore, Prophet Muhammad is very dear and very close to the heart of every Muslim. Since Muslim are sensitive to this issue, in whatever circumstance those who do not accept the teaching of Prophet Muhammad should not insult, defame or vilify him despite the freedom of speech which is granted to them in the free world. The people should be taught to respect other people belief to ensure the world is in peace. The freedom of speech and expression which are granted in all of the western countries (Spring, 20014) should not be used to insult others.

\section{References}

Ali, A. H. (2008). Infidel. New York: Simon and Schuster.

Andrea, T. (2013). Mohammed: The Man and His Faith. Oxford: Routledge.

Armstrong, K. (2004). Muhammad: A Biography of the Prophet. London: Phoenix.

Armstrong, K. (1993). History of God, the 4000-year Quest of Judaism, Christianity, and Islam. New York: Ballantime Books.

Carlyle, T. et al. (1993). On Heroes, Hero-Worship \& The Heroic In History. Berkeley: University of California.

Deresky, H. et al. (2011). International Management: Managing Cultural Diversity. Australia: Pearson Higher Education.

Dowling, E. M., \& Scarlett, W. G. (2006). Encyclopaedia of Religious and Spiritual Development. California: Sage Publication.

Erickson, J. D. (1998). Islam and Postcolonial Narrative. Cambridge, UK: Cambridge University Press. http://dx.doi.org/10.1017/CBO9780511585357

Gibbon, E. (1870). History of the Saracen Empire. London: A Murray \& Sons.

Hart, M. H. (1992). The 100: A Ranking of The Most Influential Persons In History. New Jersey: Secaucus.

Lamartine, A. (1854). Histoire De La Turquie (The History of Turkey) (Vol. 2, pp. 276-277).

Lane, H. W. et al. (2012). International Management Behaviour: Leading with a Global Mindset. John Wiley and Sons.

Liow, J. P. (2009). Piety and Politics: Islamism in Contemporary Malaysia: Islamism in Contemporary Malaysia. Oxford: Oxford University Press. http://dx.doi.org/10.1093/acprof:oso/9780195377088.001.0001

Mommsen, K. (2014). Goethe and the Poets of Arabia. New York: Boydell \& Brewer.

Muir, W. (1861). The Life of Mahomet. Cornhill: Smith, Elder and Co.

Patterson, A. (2014). The International Novel. Yale: Yale University Press. http://dx.doi.org/10.12987/yale/9780300198003.001.0001

Rushdie, S. (1988). The Satanic Verse. London: Viking Press.

Spring, J. (2014). Globalization and Educational Rights: An Intercivilizational Analysis. London: Routledge.

Tritton, A. S. (2013). Islam: Belief and Practices. London: Routledge.

Van Gorder, A. C. (2014). Islam, Peace and Social Justice: A Christian Perspective. N. P.: James Clarke \& Co Ltd.

Winston, B. (2014). The Rushdie Fatwa and After: A Lesson to the Circumspect. London: Pelgrave MacMillan. http://dx.doi.org/10.1057/9781137388605

\section{Copyrights}

Copyright for this article is retained by the author(s), with first publication rights granted to the journal.

This is an open-access article distributed under the terms and conditions of the Creative Commons Attribution license (http://creativecommons.org/licenses/by/3.0/). 